\title{
Development of Tie Dye Technique and Its Impact On Students Learning Outcome and Fine Motor Development
}

\author{
Riska Yuliastanti Putri, Deasylina Da Ary \\ Elementary School Teacher of Education Department, Faculty of Education, Universitas Negeri Semarang \\ Corresponding email: riskayuliastanti4@gmail.com
}

\begin{abstract}
This study aims to develop a color barrier technique in the class III charge of Cultural Arts and Skills at SDN Purwoyoso 06 Ngaliyan, Semarang. This research is a Research and Development $(\mathrm{RnD})$ research with steps namely: potential and problems, data collection, product design, design validation, design revision, product testing, product revision, usage testing, product revision, and final product. The population of this study was 42 third grade students of SDN Purwoyoso 06 Ngaliyan Semarang. Data analysis techniques use product data analysis, learning outcomes, and student activities. The results of the study showed: (1) the development of color barrier techniques, namely the media and tools used and the motives produced. Based on expert validation shows the color barrier technique in the test of learning techniques experts and material get a percentage of $96.4 \%$ and $97.5 \%$ with very feasible criteria; (2) the use of color barrier techniques influences the effectiveness of SBK learning as evidenced by student learning outcomes with an average student score of 78.33\%; (3) student activities obtain an average percentage of $94.83 \%$ with very high criteria. The conclusions of the study showed that the results of the development of the color barrier technique based on the validation of the learning techniques experts and the material fulfilled the criteria were feasible, could improve the effectiveness of student learning and activity.
\end{abstract}

Keywords: Tie Dye Technique, Learning Outcomes, Fine Motor development, SBK.

\section{Introduction}

Arts, Culture, and Craftsmanship subject sometimes is undervalued and regarded as insignificant; thus, it is often marginalized from the other subjects in the curriculum. The curriculum taking into effect in Primary Schools places arts, culture, and craftsmanship subject at the insignificant and marginal place. The compaction of learning materials of arts, culture, and craftsmanship subject causes inconsistency between application and the outcome of the initial learning target. In Undang-Undang Republik Indonesia Nomor 20 Tahun 2003 BAB X pasal 37 (Act of Republic of Indonesia (2003:23) Chapter X Article 37) atates that Curriculum for primary and secondary education is obliged to include arts, culture, and craftsmanship not only in one subject because the culture itself includes all life aspects. The culture, however, is not discussed separately but it is integrated in the culturalbased arts. Arts, Culture, and Craftsmanship subject is taught at schools due to its uniqueness, meaningfulness, and usefulness to the needs of the students which is situated on the aesthetic experience in the activities of expression, creation, and appreciation.

There have been many problems appearing in the field regarding the learning and teaching of arts subject. This statement is advocated by the study carried out by Ni Luh Ratreni, A.A. Gede Agung, and I Wayan Suwatra in a journal published in 2012 titled
Penerapan Metode Pemberian Tugas dan Kegiatan $3 M$ untuk Meningkatkan Perkembangan Motorik Halus Anak Kelompok B TK Wid ya Kumara Sari Tunjung (Application of Assignment Giving and 3M Activities as Method to Improve the Children's Fine Motor Development in B-Group in TK Widya Kumara Sari Tanjung). From the observation, I found some problems in TK Widya Kumara Sari Tunjung. Among them are the kids' poor fine motor development and the teacher only uses paper and pencil when teaching so the students looks unconcerned and uninterested. It can be viewed when the students did not pay attention to the teacher, they make noises in the class, and they were apathetic. Therefore, it needs the application of task-giving and $3 \mathrm{M}$ activities to improve the fine motor development for the kids in Group B TK Widya Kumara Sari Tunjung.

The phenomenon appearing in TK Widya Kumara Sari Tunjung appeared, too, in SDN Purwoyoso 06 Ngaliyan, Semarang. When analyzing the students learning outcome in SDN Purwoyoso 06 I found that in the Arts, Culture, and Craftsmanship subject, the students of all grades had passed the determined mastery learning point for Arts, Culture, and Craftsmanship subject, i.e. 75. Grade III, however, had the lowest average point. Of 42 students comprising 21 male and 21 female students, although all students passed the mastery learning criteria for Arts, Culture, and Craftsmanship subject, I found numerous 
problems. From the interviews that I did with the teacher of the grade III, I found that actually there were many students whose works were below the standard that cause their learning outcome below the mastery learning criteria. The teacher, however, could not give points below KKM because for the teacher, they were their works and their creativities. She just appreciated their efforts because they had accomplished the assignment she gave. Based on the observation that I carried out, the problem appearing in terms of learning implementation is that the teacher had not applied the effective learning technique and she just showed a picture, then the students were asked to imitate the picture without being taught the technique and how to draw a good picture. The teacher gave some reasons such as she had been too busy preparing the teaching administration, doing the jobs outside the schools, so she did not have enough time to teach the drawing techniques so that the students learning outcome and fine motor did not develop well.

Many preceding studies of the same type on the relations between learning facilities and learning outcomes showed the relatively similar results. The preceding study of the same type conducted and published in a journal was the one conducted by Ni Kadek Mei Hendrawati in e-Journal PG-PAUD Universitas Pendidikan Ganesha Volume 2 No 1 Tahun 2014 (VoL. 2:1/2014) titled "Penerapan Metode Demonstrasi Melalui Kegiatan Melukis dengan Cara Inkonvensional untuk Meningkatkan Keterampilan Motorik Halus Anak" (Application of Demonstration Method through Painting Unconventionally to Improve the Kids Fine Motor Skill). The study aimed to find the fine motor skill improvement on the kids of Group B in Taman Kanak-kanak Melati Payangan Gianyar when demonstration method was applied through unconventional painting activities. Data of the study were analyzed through descriptive statistical and quantitative descriptive analysis methods. The data analysis shows that fine motor skill improves through application of demonstration method through unconventional painting, i.e. at cycle $I$ it was $39.68 \%$ which means very low, apparently it improved at cycle II into $87.4 \%$ which is included into active category. Thus, the students' fine motor skill improves from cycle I to cycle II at rate $47.72 \%$. The investigation data show that the application of demonstration method through unconventional painting can improve the fine motor skill of the kids in Group B of TK Melati Payangan Gianyar.

Based on the description above, I developed a learning technique in order to improve grade III students learning outcomes and fine motor development in SDN Purwoyoso 06 Ngaliyan. I am interested in doing investigation on "Pengembangan Teknik Rintang Warna Terhadap Hasil Belajar dan Perkembangan Motorik Halus Muatan Seni Budaya Dan Keterampilan Siswa Kelas III SDN Purwoyoso 06 Ngaliyan Semarang" (The Impact of Development of Tie Dye Technique on Learning Outcomes and Fine Motor Development in Arts, Culture, and Craftsmanship Subject of Grade III Students in SDN Purwoyoso 06 Ngaliyan Semarang).

This study aims to develop tie dye technique in order to improve the students learning outcomes and fine motor development in SDN Purwoyoso 06 Ngaliyan on Arts, Cultures, and Craftsmanship subject particularly the lesson of creating two-dimension artworks.

\section{Research Methods}

The type of this research is (Research and Development). The design of research and development scientifically can be defined as the research method applied to study, to design, to produce, and to assess validity and the effectiveness of the produced products. In this study I applied Research and Development method comprising ten stages, i.e.: (1) Problem identification, (2) Information Collecting, (3) Designing Preliminary Form of Product, (4) Preliminary Field Testing, (5) Preliminary Product Revision, (6) Small-Group Field Testing, (7) Operational Product Revision, (8) Large-Group Field Testing, (9) Main Product Revision, (10) Final Product. In this investigation I develop a technique of painting, i.e. tie dye technique for Arts, Culture, and Craftsmanship subject for grade III students in SDN Purwoyoso 06 Ngaliyan Semarang. At tenth stage, I just made the final product to improve grade III students learning outcomes and fine motor development in SDN Purwoyoso 06 Ngaliyan and did not produce it massively.

In this study I used two variables, i.e. independent variable and dependent variable. Variable for the research is the certain activity the scholar determined to study so he will get information then he can draw a conclusion 
(Sugiyono: 2015:61). In this study I used three variables, i.e independent variable, i.e. tie dye technique development (X). Dependent variables comprise learning outcomes $\left(\mathrm{Y}_{1}\right)$ and fine motor skill $\left(\mathrm{Y}_{2}\right)$.

The data for this study were collected through two methods, i.e. test and non-test. The test I conducted was performance test. While, the non-test technique that I took comprises observation, interviews documentation, and enquette fulfillment. The questionnaires that will be used were tested in advance to find if the questionnaires can be used to collect the valid and reliable data. The trial was conducted to 30 respondents beyond the population and beyond the samples. The data were analyzed using for types of analysis methods, i.e. analysis for tie dye technique feasibility validation data, analysis of students learning outcome and fine motor development in terms of applying tie dye technique, analysis of data on students and teachers' responses to arts, culture, and craftsmanship subject by applying tie dye technique, and analysis of data on students activities.

\section{Results And Discussion}

Based on the table of students needs we can see that we need to apply a new learning method that can stimulate the enthusiasm and can improve the students fine motor skill in order to be better skilled in terms of creating two-dimensional artworks. The technique I develop is tie dye technique to solve various problems regarding students learning outcomes and fine motor skill as well as the implementation of the learning of creating twodimension artworks in Arts, Culture, and Craftsmanship subject. Based on the teachers needs table, the recommendations given by the teacher in terms of the to-be-applied learning method development broadly is as follows: (1) the technique is interested to apply to the students, (2) the developed technique is applicable, understandable, and effective, (3) the developed technique can improve the students fine motor skill so it can improve the students learning outcomes.

Based on the score recapitulation of the assessment made by the assessors, the tie dye technique meets the criteria of "excellent" category for the media feasibility at rate of $96 \%$ and for learning materials feasibility at rate of 97\%. Media and learning materials assessors also gave feedback and suggestions on the assessment sheets. The feedback and suggestions from the assessors will be used as reference to revise the product before it is experimented to the small and large groups.

Based on the questionnaires filled out by grade III students in III SDN Purwoyoso 06 on the tie dye technique trial to create twodimension works, of 38 students, I found several aspects scored 38 at percentage of $100 \%$, i.e. aspect number 1, 2, 5, 6, 7, 8, and 10. Aspect 4 and 9 scored 36 at rate for $94 \%$. And aspect 3 scored 35 at rate of $92 \%$. The overall rate of the students' responses of the Arts, Culture, and Craftsmanship learning by applying tie dye technique was $98 \%$ and it is classified into "good" category.

Based on the questionnaire filled out by the teacher of grade III in SDN Purwoyoso 06 Ngaliyan on the tie dye technique trial to create two-dimension works, the teacher thinks that there are 9 of 10 indicators scored 4 at rate of $100 \%$. Ana aspect 4 scored 3 at rate of $75 \%$, i.e. on the media aspect, the learning media is easy to be applied by the students and is appropriate for their development and their way of thinking. The overall rate of the teacher's responses of the Arts, Culture, and Craftsmanship learning by applying tie dye technique was $97.5 \%$ and it is classified into "excellent" category.

Based on the recap, in terms of creating two-dimension works using tie dye technique conducted three times, I found the improvement on the students' fine motor skill. The created products improve at every lesson. The average percentage of the students' activeness is $94.83 \%$ which means highly active and in every lesson their motor fine skill improves.

\section{References}

Arikunto, Suharsimi. 2015. Metode Penelitian Pendidikan. Bandung: Alfabeta.

Sudjana, Nana. 2014. Penilaian Hasil Proses Belajar dan Mengajar. Bandung: Remaja Rosdakarya.

Widoyoko, Eko Putro. 2016. Teknik Penyusunan Instrumen Penelitian. Yogyakarta: Pustaka Belajar.

Daryanto. 2013. Media Pembelajaran. Yogyakarta: Gava Media. 